\title{
Sexual dimorphism, metabolic, and oxidative stress markers of African catfish (Clarias garepinus and Heterobranchus longifilis) broodstock in Southwest Nigeria
}

Olatunji Abubakar Jimoh ${ }^{1 *}$ (D, Christie Oluwatosin Raimi ${ }^{1}$, Ebenezer Temitope Adebayo ${ }^{2}$, Bolaji Fatai Oyeyemi ${ }^{3}$ and Matthew Ayobami Odedele ${ }^{1}$

\begin{abstract}
Background: Sexual dimorphism in metabolic and oxidative stress markers of Clarias gariepinus and Heterobranchus longifilis found in southwest Nigeria was investigated. C. garepinus and H. longifilis broodstock weighing $2.54 \pm 0.12$ and $2.11 \pm 0.15 \mathrm{~kg}$ consisting of 20 males and females each per species were sourced from southwest Nigeria. Fishes conditioned conditioning for breeding, blood samples were collected, and serum obtained to assess metabolic and oxidative stress indices using standard procedures.

Results: The results obtained show that serum albumin, triglyceride, low-density lipoprotein, alanine aminotransferase, and total antioxidant activity of Clarias garepinus were significantly $(p<0.05)$ higher than Heterobranchus longifilis. Superoxide dismutase of males was significantly $(p<0.05)$ superior to females in both species. The total antioxidant activity of males was significantly $(p<0.05)$ superior to females in Heterobranchus longifilis. Serum catalase, glutathione peroxidase and lipid peroxidation were not affected by sex and species differences. Superoxide dismutase activity and some non-enzyme antioxidants could account for superior total antioxidant activity in males despite similar lipid peroxidation.

Conclusion: Catfish broodstocks of Heterobranchus longifilis possess superior total antioxidant activity than Clarias gariepinus owing to its superior non-enzyme antioxidants fraction. In both clariid species, males have better antioxidant defence than females.
\end{abstract}

Keywords: African catfish, Antioxidants, Lipid peroxides, Sexual dimorphism, Genetic diversity

\section{Background}

The projected increase in world population, high preference for fish, and fisheries product in Africa account for growth in global demand for fish (FAO, 2000). Clarias gariepinus and Heterobranchus longifilis are the two commonly cultured Clariid fish and are aquaculture candidate to narrow the gap between demand and supply of animal protein in developing countries (Bichi, Isyaku,

\footnotetext{
* Correspondence: abubakarjimoh2011@gmail.com

${ }^{1}$ Animal Production Unit, Agricultural Technology Department, Federal

Polytechnic Ado Ekiti, Ado Ekiti, Ekiti State, Nigeria

Full list of author information is available at the end of the article
}

Danba, Kurawa, \& Nayawo, 2014). They are reared all over Nigeria and have excellent commercial value in the markets (Owodeinde \& Ndimele, 2011). Clarias gariepinus is a tasty, hardy, efficient feed converter that grows to $7.0 \mathrm{~kg}$ and can tolerate poor water quality conditions. In comparison, Heterobranchus spp. can grow to a size of about $14.0 \mathrm{~kg}$ (Idodo-Umeh, 2003). Methods of artificial seed propagation of African catfish are costly in Nigeria, and hatchery operators are usually scared of the vast quantities of spawning hormone required for induced breeding and high price due to the large size of broodstock (Bichi et al., 2014). 
Oxidative stress is an unavoidable aspect of aerobic life, with elevated production of reactive oxygen species (ROS) the leading cause, with mitochondrial respiration being the primary endogenous ROS source (Odo et al., 2017). The extent of malonaldehyde (MDA) is determined by a balance between oxidants' production and removal/scavenging of those oxidants by antioxidants. Oxidative stress biomarkers have been used to assess the responses of aquatic organisms to various biotic stressors (pathogenic microbes) and environmental perturbations (heavy metals, salinity fluctuations, and herbicides) (Adeyemi, 2014). Most reports on oxidative stress in African catfish in response to environmental stressors do not account for gender differences in the animals' biological system and defence. The possibility of gender differences in oxidative biomarkers might influence the narrative or implications of reports. It is imperative to establish these facts for future research outlays. There has been a scarcity of data on sex differences in African catfish's performance traits raised in pond cultures (Chwastowska-Siwiecka et al., 2016). African catfish (Clarias gariepinus and Heterobranchus longifilis), despite the economic importance of these species, little is known about their natural populations' genetic background for short differentiation and determination of the genetic connection between them (Suleiman, 2017). The sensitivity of fish to stress differs markedly among species, and the degree of stress affects reproductive performance in broodstock (Sule, 2010). This study aims to assess sexual dimorphism in oxidative stress markers of two clariid species in Southwest Nigeria.

\section{Methods}

\section{Experimental animals and management}

Forty catfish broodstock each of C. garepinus (CG) and H. longifilis (HL) (20 males and 20 females per species) were procured from reputable breeder farms in Ogun Osun, Ekiti, and Ondo State Nigeria. All the broodstocks were of similar weight of $2.54 \pm 0.12$ and $2.11 \pm 0.15 \mathrm{~kg}$ for $C$. garepinus and $H$. longifilis. The basis for selecting the broodstocks was the readiness of the genitals; the gravid female was based on swollen, reddish genital opening while the male was based on reddish and pointed genital papillae. Brood stocks were transported in plastic troughs from the farms to the fisheries laboratory. Brood stocks were acclimated and conditioned in separate tanks for 1 week and were fed with $40 \%$ crude protein commercial pelleted feed at $3 \%$ body weight twice daily at 9.00 and $18.00 \mathrm{~h}$.

\section{Blood sample collection and assay}

The broodstock was for breeding. Fasting blood samples were collected from all fishes into plain sample bottles before the breeding commenced. Blood samples were centrifuged at $3000 \mathrm{rpm}$ for 15 min immediately to obtain serum. The serum was assayed for glucose, albumin, cholesterol, high-density lipoprotein (HDL), triglycerides, low-density lipoprotein (LDL), creatinine, Alkaline phosphatase (ALP), aspartate aminotransferase (AST), and alanine aminotransferase (ALT) using Calbiotech, Inc., Biochemical Kit and its designated protocol. The oxidative markers such as total antioxidant activity, lipid peroxidation, catalase (CAT), glutathione peroxidase (GPx), and superoxide dismutase (SOD) were assayed as described in Jimoh (2019).

Determination of serum total antioxidant activities was carried out according to Koracevic, Koracevic, Djordjevic, Andrejevic, and Cosic (2001), the reactive mixture containing $0.5 \mathrm{~mL}$ of a $(10 \mathrm{mmol} / \mathrm{L}) \mathrm{Na}$-Benzoate, 0.2 $\mathrm{mL}$ of $\mathrm{H}_{2} \mathrm{O}_{2}(10 \mathrm{mmol} / \mathrm{L}), 0.49 \mathrm{ml}$ of phosphate buffer $(100 \mathrm{mmol} / \mathrm{L}, \mathrm{pH}=7.4)$ (prepared by mixing $19.5 \mathrm{ml}$ of $\mathrm{KH}_{2} \mathrm{PO}_{4}(100 \mathrm{mmol} / \mathrm{L})$ with $80.5 \mathrm{ml}$ of $\mathrm{Na}_{2} \mathrm{HPO}_{4}(100$ $\mathrm{mmol} / \mathrm{L}$ ), then adjusted the $\mathrm{pH}$ to 7.4 and $0.2 \mathrm{ml}$ of FeEDTA complex $(2 \mathrm{mmol} / \mathrm{L})$ (prepared freshly by mixing equal volumes of EDTA $(2 \mathrm{mmol} / \mathrm{L})$. Ferrous ammonium sulfate $(2 \mathrm{mmol} / \mathrm{L})$, then left at $25{ }^{\circ} \mathrm{C}$ for $60 \mathrm{~min}$. Ten microliters of the blood serum was added to the latter reactive mixture and was incubated at $37{ }^{\circ} \mathrm{C}$ for 60 min. Finally, $1 \mathrm{ml}$ glacial acetic acid $(20 \mathrm{mmol} / \mathrm{L})$ and 1 $\mathrm{ml}$ thiobarbituric acid $(0.8 \% \mathrm{w} / \mathrm{v}$ in $100 \mathrm{ml}$ of $50 \mathrm{mmol} /$ $\mathrm{L} \mathrm{NaOH}$ ) were added, and the absorbance at $532 \mathrm{~nm}$ was measured spectrophotometrically after incubation at $100{ }^{\circ} \mathrm{C}$ for $10 \mathrm{~min}$. Total antioxidant capacity was calculated according to the following formula:

$$
\begin{aligned}
& \text { Total antioxidant activity }(\mathrm{mmol} / \mathrm{L}) \\
& =(\mathrm{CUA})(\mathrm{K}-\mathrm{A}) /(\mathrm{K}-\mathrm{UA})
\end{aligned}
$$

Where CUA (mmol/L); concentration of uric acid; K: absorbance of the control (K1 - K0); A: absorbance of the sample (A1 - A0); UA: absorbance of uric acid solution (UA1 - UA0)

In the assay for lipid peroxidation, the reaction mixture in a total volume of $3.0 \mathrm{ml}$ contained $1.0 \mathrm{ml}$ serum and $1.0 \mathrm{ml}$ of TCA $(0.67 \%)$. All the test tubes were placed in a boiling water bath for $45 \mathrm{~min}$. The tubes were shifted to the ice bath and then centrifuged at 2500 $\mathrm{rpm}$ for $10 \mathrm{~min}$. The amount of malondialdehyde formed in each of the samples was assessed by measuring the supernatant's optical density at $532 \mathrm{~nm}$.

\section{Superoxide dismutase}

The reaction mixture includes $2.1 \mathrm{ml}$ of $50 \mathrm{mM}$ buffer, $0.02 \mathrm{ml}$ of enzyme source, and $0.86 \mathrm{ml}$ of distilled water. The reaction was initiated with $0.02 \mathrm{ml}$ of $10 \mathrm{mM}$ pyrogallol, and change in absorbance monitored at $420 \mathrm{~mm}$. One unit of SOD is defined as that amount of enzyme required to inhibit to auto-oxidation of pyrogallol by 
$50 \%$ in the standard assay system of $3 \mathrm{ml}$. The specific activity is expressed as unit/min/mg protein.

\section{Glutathione peroxidase activity}

$0.5 \mathrm{ml}$ of $0.4 \mathrm{M}$ buffer, $\mathrm{pH} 7.0,0.2 \mathrm{ml}$ enzyme source, $0.2 \mathrm{ml}$ of $2 \mathrm{mM} \mathrm{GSH}$, and $0.1 \mathrm{ml}$ of $0.2 \mathrm{mM} \mathrm{H}_{2} \mathrm{O}_{2}$ were added incubated at room temperature for $10 \mathrm{~min}$ along with the control tube containing all reagents except enzyme source. The reaction arrested by adding $0.5 \mathrm{ml}$ of $10 \% \mathrm{TCA}$, centrifuged at $4000 \mathrm{rpm}$ for $5 \mathrm{~min}$, and the glutathione (GSH) content in $0.5 \mathrm{ml}$ of supernatant was estimated. The activity expressed as a microgram of GSH consumed/min/mg protein.

\section{Catalase activity}

The assay system contains $1.9 \mathrm{ml}$ of $0.05 \mathrm{M}$ buffer, $\mathrm{pH}$ 7.0 , and $1.0 \mathrm{ml}$ of $0.059 \mathrm{M} \mathrm{H}_{2} \mathrm{O}_{2}$. The reaction is initiated by the addition of $0.1 \mathrm{ml}$ enzyme source. The decrease in absorbance is monitored at $1 \mathrm{~min}$ interval for 5 $\min$ at $240 \mathrm{~nm}$, and activity is expressed as nanomoles of $\mathrm{H}_{2} \mathrm{O}_{2}$ decomposed $/ \mathrm{min} / \mathrm{mg}$ protein.

\section{Statistical analysis}

Data obtained were subjected to $t$ test at $p=0.05$ using the general linear model procedure of IBM SPSS Version 25 after multivariate analysis revealed no interaction between species and sex.

\section{Results}

The result of metabolic and oxidative status of Clarias garepinus and Heterobranchus longifilis is shown in Table 1. Serum albumin, triglyceride, and alanine aminotransferase of Clarias garepinus were significantly $(p<0.05)$ higher than values obtained for Heterobranchus longifilis. However, serum cholesterol, LDL, and total antioxidant activity of Heterobranchus longifilis were significantly $(p<0.05)$ higher than Clarias garepinus. Other parameters assessed had similar statistical values in both clariid species. Sexual dimorphism in metabolic and oxidative status of Heterobranchus longifilis is shown in Table 2. Serum cholesterol, low-density lipoprotein, and aspartate aminotransferase of females were significantly $(p<0.05)$ higher than values obtained for males. However, Superoxide dismutase and total antioxidant activity of males were significantly $(p<0.05)$ superior to females. Other parameters assessed were not influenced by sex as they had similar statistical values. Sexual dimorphism in metabolic and antioxidant status of Clarias garepinus is shown in Table 3. All parameters assessed had statistically similar values across both sexes except serum superoxide dismutase and albumin. The superoxide dismutase and albumin activity of male Clarias garepinus were significantly $(p<0.05)$ higher.

\section{Discussion}

The result shows that HL has higher cholesterol-LDL compared with higher triglyceride level in CG. This could be associated with a higher growth rate characteristic of HL, increasing fat metabolism, and deposition. Albumin is a fraction of the total protein that plays an active role in metabolism and protein synthesis, and higher activity in CG could depict more significant metabolism for cellular growth (Amin \& Hashem, 2012). Lower LDL in CG infers the reduction in the high circulation fat bound proteins, which may be due to lower

Table 1 Metabolic and antioxidant status in the two catfish species

\begin{tabular}{|c|c|c|c|}
\hline & Clarias garepinus & Heterobranchus longifilis & $p$ value \\
\hline Glucose, $\mathrm{mmol} / \mathrm{l}$ & 63.53 & 49.53 & 0.48 \\
\hline Albumin, $g / l$ & $366.30^{\mathrm{a}}$ & $285.00^{\mathrm{b}}$ & 0.00 \\
\hline Cholesterol, $\mathrm{mmo} / \mathrm{l}$ & $35.35^{\mathrm{b}}$ & $38.20^{\mathrm{a}}$ & 0.05 \\
\hline Triglyceride, $\mathrm{mmol} / \mathrm{l}$ & $5.01^{\mathrm{a}}$ & $3.34^{\mathrm{b}}$ & 0.08 \\
\hline High-density lipoprotein, $\mathrm{mmol} / \mathrm{l}$ & 22.07 & 22.43 & 0.35 \\
\hline Low-density Lipoprotein, mmol/l & $11.98^{\mathrm{b}}$ & $26.32^{\mathrm{a}}$ & 0.02 \\
\hline Alkaline phosphatase, IU/I & 1.86 & 1.78 & 0.17 \\
\hline Creatinine, $\mathrm{mmol} / \mathrm{l}$ & 4.90 & 3.69 & 0.17 \\
\hline Aspartate amino transferase, U/L & 30.51 & 28.40 & 0.1 \\
\hline Alanine amino transferase, $\mathrm{u} / \mathrm{l}$ & $6.56^{\mathrm{a}}$ & $4.40^{\mathrm{b}}$ & 0.03 \\
\hline Total antioxidant activity (mmol/liter) & $6.44^{\mathrm{b}}$ & $14.00^{\mathrm{a}}$ & 0.01 \\
\hline Lipid peroxidation ( $\times 10^{-2}$ TBARS/mg protein) & 1.35 & 1.39 & 0.39 \\
\hline Superoxide dismutase (U/min/mg protein) & 2.36 & 2.33 & 0.4 \\
\hline Catalase ( $\mathrm{nm} \mathrm{H} \mathrm{H}_{2} \mathrm{O}_{2} / \mathrm{min} / \mathrm{mg}$ protein) & 9.08 & 9.28 & 0.68 \\
\hline Glutathione peroxidase ( $\mu \mathrm{g} \mathrm{GSH} / \mathrm{min} / \mathrm{mg}$ protein) & 50.96 & 36.52 & 0.26 \\
\hline
\end{tabular}

${ }^{\mathrm{ab}}$ Means in the same row with different superscripts are significantly $(p<0.05)$ different. $p$ value probability value 
Table 2 Sexual dimorphism in metabolic and antioxidant status of Heterobranchus longifilis

\begin{tabular}{|c|c|c|c|}
\hline & Female & Male & $p$ value \\
\hline Glucose, $\mathrm{mmol} / \mathrm{l}$ & 48.13 & 50.23 & 0.11 \\
\hline Albumin, $g / l$ & 292.50 & 281.25 & 0.90 \\
\hline Cholesterol, mmo/l & $64.80^{\mathrm{a}}$ & $24.89^{b}$ & 0.02 \\
\hline Triglyceride, mmol/l & 3.46 & 3.28 & 0.35 \\
\hline High-density lipoprotein, $\mathrm{mmol} / \mathrm{l}$ & 23.95 & 21.67 & 0.15 \\
\hline Low-density lipoprotein, mmol/l & $39.28^{\mathrm{a}}$ & $13.36^{\mathrm{b}}$ & 0.05 \\
\hline Alkaline phosphatase, IU/I & 1.29 & 2.02 & 0.13 \\
\hline Creatinine, $\mathrm{mmol} / \mathrm{l}$ & 1.48 & 4.79 & 0.31 \\
\hline Aspartate amino transferase, $\mathrm{U} / \mathrm{L}$ & $44.81^{\mathrm{a}}$ & $20.20^{b}$ & 0.05 \\
\hline Alanine amino transferase, $u / l$ & 5.02 & 4.09 & 0.65 \\
\hline Total antioxidant activity (mmol/liter) & $1.17^{\mathrm{b}}$ & $16.57^{\mathrm{a}}$ & 0.02 \\
\hline Lipid peroxidation ( $\times 10^{-2}$ TBARS/mg protein) & 1.76 & 1.26 & 0.68 \\
\hline Superoxide dismutase (U/min/mg protein) & $0.33^{b}$ & $3.00^{\mathrm{a}}$ & 0.05 \\
\hline Catalase ( $\mathrm{nm} \mathrm{H} \mathrm{H}_{2} \mathrm{O}_{2} / \mathrm{min} / \mathrm{mg}$ protein) & 8.07 & 9.88 & 0.23 \\
\hline Glutathione peroxidase ( $\mu \mathrm{g} \mathrm{GSH} / \mathrm{min} / \mathrm{mg}$ protein) & 16.05 & 44.71 & 0.15 \\
\hline
\end{tabular}

${ }^{\mathrm{ab}}$ Means in the same row with different superscripts are significantly $(p<0.05)$ different. $p$ value probability value

total cholesterol and higher protein (albumin specifically; it is the fraction of protein responsible for metabolism).

Total antioxidant activity is a combination of enzymatic (SOD, GPx, CAT) and non-enzymatic (vitamins, bilirubin, glutathione) antioxidants in the biological system (Jimoh, Ewuola, \& Balogun, 2017; Jimoh, Ihejirika, Balogun, \& Uwaeziozi, 2018). This study suggests that the nonenzymatic antioxidants in HL account for its higher antioxidant activity since all enzymatic antioxidants assessed were similar in both species of catfish. This is coupled with the fact that the rate of lipid peroxidation is similar in both catfish species. This reveals that similar free radicals and reactive oxygen species scavenging ability in the serum of both catfish.

The trend of results shows that total cholesterol and LDL of female HL were superior to males. This could be associated with its requirement for oogenesis and steroid synthesis for the regulation of ovulation. Cholesterol is

Table 3 Sexual dimorphism in metabolic and antioxidant status of Clarias garepinus

\begin{tabular}{|c|c|c|c|}
\hline & Female & Male & $p$ value \\
\hline Glucose, $\mathrm{mmol} / \mathrm{l}$ & 72.84 & 46.76 & 0.80 \\
\hline Albumin, $g / l$ & $358.85^{\mathrm{b}}$ & $379.73^{a}$ & 0.02 \\
\hline Cholesterol, mmo/l & 37.59 & 31.32 & 0.66 \\
\hline Triglyceride, $\mathrm{mmol} / \mathrm{l}$ & 4.94 & 5.15 & 0.51 \\
\hline High-density lipoprotein, $\mathrm{mmol} / \mathrm{l}$ & 22.54 & 21.31 & 0.33 \\
\hline Low-density lipoprotein, $\mathrm{mmol} / \mathrm{I}$ & 15.06 & 7.67 & 0.19 \\
\hline Alkaline phosphatase, IU/I & 1.92 & 1.76 & 0.30 \\
\hline Creatinine, $\mathrm{mmol} / \mathrm{l}$ & 2.83 & 8.63 & 0.79 \\
\hline Aspartate amino transferase, U/L & 30.89 & 29.83 & 0.76 \\
\hline Alanine amino transferase, $\mathrm{u} / \mathrm{l}$ & 7.23 & 5.48 & 0.13 \\
\hline Total antioxidant activity (mmol/liter) & 6.10 & 6.97 & 0.3 \\
\hline Lipid peroxidation ( $\times 10^{-2}$ TBARS/mg protein) & 1.39 & 1.30 & 0.22 \\
\hline Superoxide dismutase (U/min/mg protein) & $1.67^{\mathrm{b}}$ & $3.47^{\mathrm{a}}$ & 0.00 \\
\hline Catalase ( $\mathrm{nm} \mathrm{H} \mathrm{H}_{2} \mathrm{O}_{2} / \mathrm{min} / \mathrm{mg}$ protein) & 9.34 & 8.62 & 0.16 \\
\hline Glutathione peroxidase ( $\mu \mathrm{g} \mathrm{GSH} / \mathrm{min} / \mathrm{mg}$ protein) & 38.93 & 67.80 & 0.26 \\
\hline
\end{tabular}

${ }^{\mathrm{ab}}$ Means in the same row with different superscripts are significantly $(p<0.05)$ different. $p$ value probability value 
the pre-procursor for steroid hormone synthesis and its influences the cyclicity of female reproductive activity. This is corroborated by the report that reproductive status influences serum cholesterol in the different reproductive cycle stages (Sutharshiny, Sivashanthinni, \& Thulasitha, 2013). The AST levels are within the normal range, and difference in AST synthesis would be suggested in both species. This is because the higher AST activity was not accompanied by creatinine and could not indicate toxicity.

The trends of superior antioxidant activity in male HL suggest that its superiority is accounted for by higher SOD activity. However, both sexes have a similar rate of lipid peroxidation despite the superior antioxidant profile in males. This could indicate that the normal range of lipid peroxides in catfish serum. The results indicate that a superior total antioxidant in male HL could be accounted for by non-enzyme antioxidants and SOD. This agrees with Sayed and Khalil (2016) that total antioxidant capacity considers the cumulative, synergistic action of all the antioxidants present and providing an integrated parameter rather than the simple sum of measurable antioxidants. Measurement of individual antioxidant may give a misleading picture because antioxidants work in concert through chain breaking reactions.

Contrary to trends of result in HL, male CG had a higher albumin activity than females; this could be associated with higher protein metabolism in males due to their superior growth rate. Amin and Hashem (2012) reported that serum protein changes are associated with free amino acids metabolism and their synthesis in the liver in catfish. The SOD activity was superior in male CG compared to females, a trend that is similar to both HL and CG. Higher antioxidant activity in male catfish could be a defence strategy against testosterone-bound oxidative load; as reported by Sayed and Khalil (2016), higher testosterone levels at the reproductive phase have higher levels of oxidative damage exemplified by decreased antioxidant capacity during reproduction.

The rate of lipid peroxidation in both species was similar and agrees with Chwastowska-Siwiecka et al. (2016) that lipid peroxidation in African catfish's meat was not influenced by gender. Oxidative stress is also induced due to three factors: an increase in oxidant generation, a decrease in antioxidant protection, and failure to repair oxidative damage (Jimoh, 2019; Sujatha, Joseph, \& Sumi, 2010). Higher superoxide activity trends (male catfish of both species) and total antioxidant activity (male $\mathrm{HL}$ ) in this study reveal higher antioxidant protection against oxidative stress in the HL and male African catfish. In oxidative stress-prone conditions, they could be more resistant to oxidative damage than CG and females. This emphasizes the importance of oxidative stress management; as suggested by Sule (2010), stress should be minimized to guarantee optimal gamete quality and quality fish production in broodstock. This study highlight the importance of oxidative stress markers and their management in fish farming has been linked to the health of farmed fish because it adversely impacts fish welfare, growth, immunity and reproduction, and more importantly, for food quality and safety for human consumption (Sayed \& Khalil, 2016). The generation of ROS is essential for the testicular cell's normal physiological function; hence, they play a vital role in normal spermatogenesis and can also lead to pathologies of the male reproductive system (Jimoh \& Ewuola, 2019). Oxidative stress associated with decreased antioxidant levels may contribute to male factor infertility (Jimoh \& Ewuola, 2018). This suggests that males' better antioxidant defence could be related to enhancing testicular health, as most infertility cases are male-related.

\section{Conclusion}

There are genetic and gender differences in oxidative stress markers in the two clariid species in southwestern Nigeria. Both clariid species possess similar lipid peroxidation, and males have better antioxidant defence than females. This study reveals that non-enzymatic antioxidants have a higher contribution to total antioxidant activity in catfish broodstock.

\section{Abbreviations \\ CG: Clarias garepinus; HL: Heterobranchus longifilis; MDA: Malonaldehyde; HDL: High-density lipoprotein; LDL: Low-density lipoprotein; ALP: Alkaline phosphatase; AST: Aspartate aminotransferase; ALT: Alanine aminotransferase; CAT: Catalase; GPx: Glutathione peroxidase; SOD: Superoxide dismutase; GSH: Glutathione}

\section{Acknowledgements}

The authors are grateful to the Tertiary Education Trust Fund of the Federal Republic of Nigeria for providing funds to undertake the research.

\section{Authors' contributions}

JOA designed and supervised the study, carried out statistical analysis, and wrote the first manuscript. OBF co-supervised the study and wrote the experimental layout. AET carried out the fieldwork, reviewed, and approved the study protocol. RCO attracted funding for the experimental protocol, read, and corrected the first manuscript. OAM managed the animals and carried out laboratory assay. All authors read and approve the final manuscript.

\section{Funding}

This article's research outcome was funded by the Tertiary Education Trust Fund TETFUND 2018 institution-based research intervention of the Nigerian Government. The fund was secured solely for conducting the research both field and laboratory analysis.

\section{Availability of data and materials}

The datasets used and analyzed during the current study are available from the corresponding author on reasonable request.

\section{Declarations}

Ethics approval and consent to participate

The Federal Polytechnic Ado Ekiti Centre for Research Innovation and Development's committee approved the study with IACUC approval no: 
FPA/EC/19/0043 and ensured the care and use of animals for the experiment followed the $\mathrm{NIH}$ guide for the care and use of laboratory animals.

\section{Consent for publication}

Not applicable

\section{Competing interests}

No competing interest exists in the research outcome presented in this article.

\section{Author details}

${ }^{1}$ Animal Production Unit, Agricultural Technology Department, Federal Polytechnic Ado Ekiti, Ado Ekiti, Ekiti State, Nigeria. ${ }^{2}$ Department of Biological Sciences, University of Medical Sciences Ondo City, Ondo City, Ondo State, Nigeria. ${ }^{3}$ Science Technology Department, Federal Polytechnic Ado Ekiti, Ado Ekiti, Ekiti State, Nigeria.

Received: 14 May 2020 Accepted: 10 May 2021

Published online: 20 May 2021

\section{References}

Adeyemi, J. A. (2014). Oxidative stress and antioxidant enzymes activities in the African catfish, Clarias gariepinus, experimentally challenged with Escherichia coli and Vibrio fischeri. Fish Physiology and Biochemistry, 40(2), 347-354. https://doi.org/10.1007/s10695-013-9847-x.

Amin, K. A., \& Hashem, K. S. (2012). Deltamethrin-induced oxidative stress and biochemical changes in tissues and blood of catfish (Clarias gariepinus): antioxidant defense and role of alpha-tocopherol. BMC Veterinary Research, 8(1), 45. https://doi.org/10.1186/1746-6148-8-45.

Bichi, A. H., Isyaku, S., Danba, E. P., Kurawa, I. A., \& Nayawo, A. A. (2014). Effect of broodstock size on egg fertilisation, hatchability and fry survival rate of African catfish (Clarias gariepinus). Bayero Journal of Pure and Applied Sciences, 7(2), 150-154.

Chwastowska-Siwiecka, l., Skiepko, N., Pomianowski, J. F., Kubiak, M. S., Woźniak, M., \& Baryczka, M. (2016). Analysis of the chemical composition and of selected physicochemical properties of meat of African catfish (Clarias gariepinus) depending on gender. Italian Journal of Food Science, 28, 391 401. https://doi.org/10.14674/1120-1770/ijfs.v68.

Food and Agriculture Organization (2000). FAO Aquaculture newsletter April 2000, (pp. 24-37).

Idodo-Umeh, G. (2003). Freshwater fishes of Nigeria (taxonomy, ecological notes, diets and utilisation), (p. 232). Benin City: Idodo Umeh Publishers Ltd.

Jimoh, O. A. (2019). Oxidative stress indicators of rabbit breeds in Ibadan, Southwest Nigeria. Bulletin of the National Research Centre, 43(62), 1-7. https://doi.org/10.1186/s42269-019-0104-z.

Jimoh, O. A., \& Ewuola, E. O. (2018). Semen characteristics, seminal biochemical and oxidative stress markers in rabbits during heat stress. Journal of Veterinary Andrology, 3(2), 35-44 http://cesica.org/publicaciones/index.php/ journal_veterinary_andrology/article/view/59/48.

Jimoh, O. A., \& Ewuola, E. O. (2019). Semen characteristics and seminal oxidative status of four breeds of Rabbit in Southwest, Nigeria. The Journal of Basic and Applied Zoology, 80(35), 1-9. https://doi.org/10.1186/s41936-019-0105-3.

Jimoh, O. A., Ewuola, E. O., \& Balogun, A. S. (2017). Oxidative stress markers in exotic breeds of rabbit during peak of heat stress in Ibadan, Nigeria. Journal of Advances in Biology and Biotechnology, 12(1), 1-9. https://doi.org/10.9734/ JABB/2017/30437.

Jimoh, O. A., Ihejirika, U. G., Balogun, A. S., \& Uwaeziozi, U. C. (2018). Antioxidative effect of mistletoe leaf meal supplemented diets in laying pullets. Archivos de Zootecnia, 67(260), 526-530 https://www.uco.es/ucopress/az/index.php/az/.

Koracevic, D., Koracevic, G., Djordjevic, V., Andrejevic, S., \& Cosic, V. (2001). Method for the measurement of antioxidant activity in human fluids. Journal of Clinical Pathology, 54(5), 356-361. https://doi.org/10.1136/jcp.54.5.356.

Odo, G. E., Agwu, E. J., Ossai, N. I., Ezea, C. O., Madu, J., \& Eneje, V. (2017). Effects of aluminium phosphide on the behaviour, haematology, oxidative stress biomarkers and biochemistry of African Catfish (Clarias gariepinus) Juvenile. Pakistan Journal of Zoology, 49(2), 433-444 http://researcherslinks.com/ current-issues/Effects-Aluminium-Phosphide-Behaviour-Haematology-Oxida tive-Stress-Biomarkers-Biochemistry-African-Catfish-Clarias-gariepinusJuvenile/20/1/340/html.

Owodeinde, F. G., \& Ndimele, P. E. (2011). Survival, growth and feed utilisation of two Clariid Catfish (Clarias garierpinus, Burchell 1822 and Heterobranchus bidorsalis, Geoffroy, 1809) and their reciprocal hybrids. Journal of Applied Ichthyology, 27(5), 1249-1253. https://doi.org/10.1111/j.1439-0426.2011.01804.x.

Sayed, A. E. D. H., \& Khalil, N. S. A. (2016). Oxidative stress induction in Monosex Nile Tilapia (Oreochromis niloticus, Linnaeus, 1758): a field study on the side effects of methyltestosterone. Journal of Aquaculture Research \& Development, 7(03), 416. https://doi.org/10.4172/2155-9546.1000416.

Sujatha, S. B., Joseph, P. S., \& Sumi, P. S. (2010). Medicinal plants and its impact on ecology, nutritional effluents and incentive of digestive enzymes on Spodoptera litura (Fabricious). Asian Journal of Agricultural Research, 4(4), 204 211. https://doi.org/10.3923/ajar.2010.204.211.

Sule, S. O. (2010). Reproductive fitness of stressed female catfish broodstock of Clarias gariepinus (Burchell, 1822). PAT, 6(1), 77-83 http://patnsukjournal.net/ Vol6No1/p7.pdf.

Suleiman I.O. (2017) Morphological and genetic characterisation of two strains of clariid fish species In Kano State, Nigeria using microsatellite markers. Doctoral thesis of the school of postgraduate studies, Ahmadu Bello University Zaria, Nigeria. pp. 8-10.

Sutharshiny, S., Sivashanthinni, K., \& Thulasitha, W. S. (2013). Lipid changes in relation to maturation and spawning of tropical double spotted queenfish Scomberoides lysan (Forsskal, 1775). Asian Journal of Animal and Veterinary Advances, 8(4), 555-570. https://doi.org/10.3923/ajava.2013.555.570.

\section{Publisher's Note}

Springer Nature remains neutral with regard to jurisdictional claims in published maps and institutional affiliations.

\section{Submit your manuscript to a SpringerOpen ${ }^{\circ}$ journal and benefit from:}

- Convenient online submission

- Rigorous peer review

- Open access: articles freely available online

- High visibility within the field

- Retaining the copyright to your article

Submit your next manuscript at $\boldsymbol{\nabla}$ springeropen.com 